\title{
Organization and copy number of initiator tRNA genes in slow- and fast-growing mycobacteria
}

\author{
M VASANTHAKRISHNA, N RUMPAL and U VARSHNEY* \\ Department of Microbiology and Cell Biology, Indian Institute of Science, Bangalore 560012 , India \\ *Corresponding author (Fax, 91-80-334-1683; Email, Varshney@cge.iisc.ernet.in).
}

\begin{abstract}
We have previously reported the isolation and characterization of a functional initiator tRNA gene, metA, and a second initiator tRNA-like sequence, metB, from Mycobacterium tuberculosis. Here we describe the fine mapping of the initiator tRNA gene locus of the avirulent ( $\mathrm{H} 37 \mathrm{Ra})$ and virulent (H37Rv) strains of $M$. tuberculosis. The genomic blot analyses show that the $1.7 \mathrm{~kb}$ (harbouring metB) and the $6.0 \mathrm{~kb}$ BamHI (harbouring metA) fragments are linked. Further, sequencing of a portion of the $6.0 \mathrm{~kb}$ fragment, in conjunction with the sequence of the $1.7 \mathrm{~kb}$ fragment confirmed the presence of an IS6110 element in the vicinity of $m e t B$. The IS element is flanked by inverted ( $28 \mathrm{bp}$, with 3 contiguous mismatches in the middle) and direct ( $3 \mathrm{bp})$ repeats considered to be the hallmarks of IS6110 integration sites. The organization of the initiator tRNA gene locus is identical in both the H37Ra and H37Rv strains and they carry a single copy of the functional initiator tRNA gene. Interestingly, the fast growing Mycobacterium smegmatis also bears a single initiator tRNA gene. This finding is significant in view of the qualitative differences in total tRNA pools and the copy number of rRNA genes in the fast- and slow-growing mycobacteria. Finally, we discuss hypotheses related to the origin of metB in $M$. tuberculosis.
\end{abstract}

\section{Introduction}

Mycobacteria consist of a closely related group of slow and fast growing microorganisms. The slow growing pathogenic Mycobacterium tuberculosis and M. leprae, and the opportunistic pathogens like $M$. avium, $M$. intracellulare and $M$. kansasi afflict immunocompromised patients. The fast growers include nonpathogens like $M$. smegmatis, and pathogens such as $M$. chelonae and $M$. fortuitum. The growth rate of an organism is generally correlated to the rate of protein synthesis which in turn is dependent upon the abundance of ribosomes and the other cellular components associated with protein biosynthesis (Bremer and Dennis 1987). The premise is supported by the presence of two ribosomal RNA operons in the fast growing mycobacteria as opposed to one in the slow growers (Bercovier et al 1986; Ji et al 1994a,b; Musser 1995). Also, qualitative differences exist in the total tRNA pools between $M$. tuberculosis and $M$. smegmatis (Bhargava et al 1990). Such unusual features of the protein synthesis machinery in the slow- and fastgrowing mycobacteria offer attractive models to study the mechanistic aspects of protein biosynthesis. Previously, we reported that $M$. tuberculosis has a single functional initiator tRNA gene (Vasanthakrishna et al 1997). To our knowledge, characterization of initiator tRNA genes from no other mycobacterial species has been reported so far.

Initiation is a major rate limiting step in protein biosynthesis. It is therefore not surprising that Escherichia coli has evolved with four functional initiator tRNA genes (Ishii et al 1984; Kenri et al 1994). We recently described the isolation and characterization of a $0.34 \mathrm{~kb}$ Aval fragment containing a functional initiator tRNA gene, $m e t A$, and a $1.7 \mathrm{~kb} B a m \mathrm{HI}$ fragment containing an initiator tRNA-like sequence, met $B$ from $M$. tuberculosis H37Ra (Vasanthakrishna et al 1997). Here we complete the description of the initiator tRNA locus in M. tuberculosis H37Ra and H37Rv by showing that metA and $m e t B$ are located on contiguous BamHI fragments, sepa-

Keywords. metA; metB; IS6110; integrative elements 
rated by an insertion element, IS6110. The element is flanked by inverted and direct repeats characteristic of IS6110 integration sites (Thierry et al 1990). In addition, we speculate on the origin of metA and metB tDNA sequences. Surprisingly, $M$. smegmatis used as a representative of fast growers shows the presence of a single initiator tRNA gene. More importantly, the isolation of metA in a larger genomic fragment would be useful to pursue the mutational analysis of the initiator tRNA gene by allelic exchange with the chromosomal copy (Pelicic et al 1997).

\section{Materials and methods}

\section{Bacterial strains and growth media}

M. tuberculosis H37Ra and $M$. smegmatis SN2 are laboratory strains and were grown in modified Youmans and Karlson's (YK) medium (Nagaraja and Gopinathan 1980). E. coli strains TG1 (Amersham) and XL1-blue (Stratagene) were grown in 2YT medium (Sambrook et al 1989). Media components were procured from HiMedia, Mumbai.

\subsection{Plasmids, enzymes, radioisotopes and biochemicals}

Plasmids pTZ-18R and -19R were from Pharmacia Amersham Biotech. Restriction endonucleases were from New England Biolabs or Gibco-BRL. Radiolabelled nucleoside triphosphates were purchased from Pharmacia Amersham
Biotech. Other biochemicals of analytical grade were from Sigma, US Biochemicals, Gibco-BRL or Merck.

\subsection{Oligodeoxyribonucleotides (oligos)}

The oligos were obtained from Bangalore Genei Pvt. Ltd., Bangalore, purified on $15 \%$ acrylamide (w/v) $8 \mathrm{M}$ urea gels (Maxam and Gilbert 1980) and desalted by gel filtration on Sephadex G-50 (Pharmacia Amersham Biotech.). An oligo, termed 'anticodon oligo', 5'CCTCTGGGTTATGAGCCC-3' complementary to positions $29-46$ of the mycobacterial initiator tRNA (figure 6A) was used in colony hybridization and genomic Southern analyses. Oligonucleotide, 5'-CGAGCGGATCCAACCCGCGTC-3' corresponding to positions -2 to 19 (Vasanthakrishna et al 1997, figure 6A) was used for probing a recombinant plasmid blot.

\subsection{Preparation of genomic DNA}

Genomic DNA from $M$. smegmatis SN2 and $M$. tuberculosis H37Ra were prepared as described (Vasanthakrishna et al 1997) and the genomic DNA of $M$. tuberculosis $\mathrm{H} 37 \mathrm{Rv}$ was a kind gift from Dr V Nagaraja.

\subsection{Southern blotting}

Genomic DNA was digested with the restriction endonucleases, separated on agarose gels using Tris-borateEDTA buffer (Sambrook et al 1989), transferred to nylon membranes (Nytran, Schleicher and Schuell) by vacuum blotting using 0.4 M NaOH (Reed and Mann 1985).
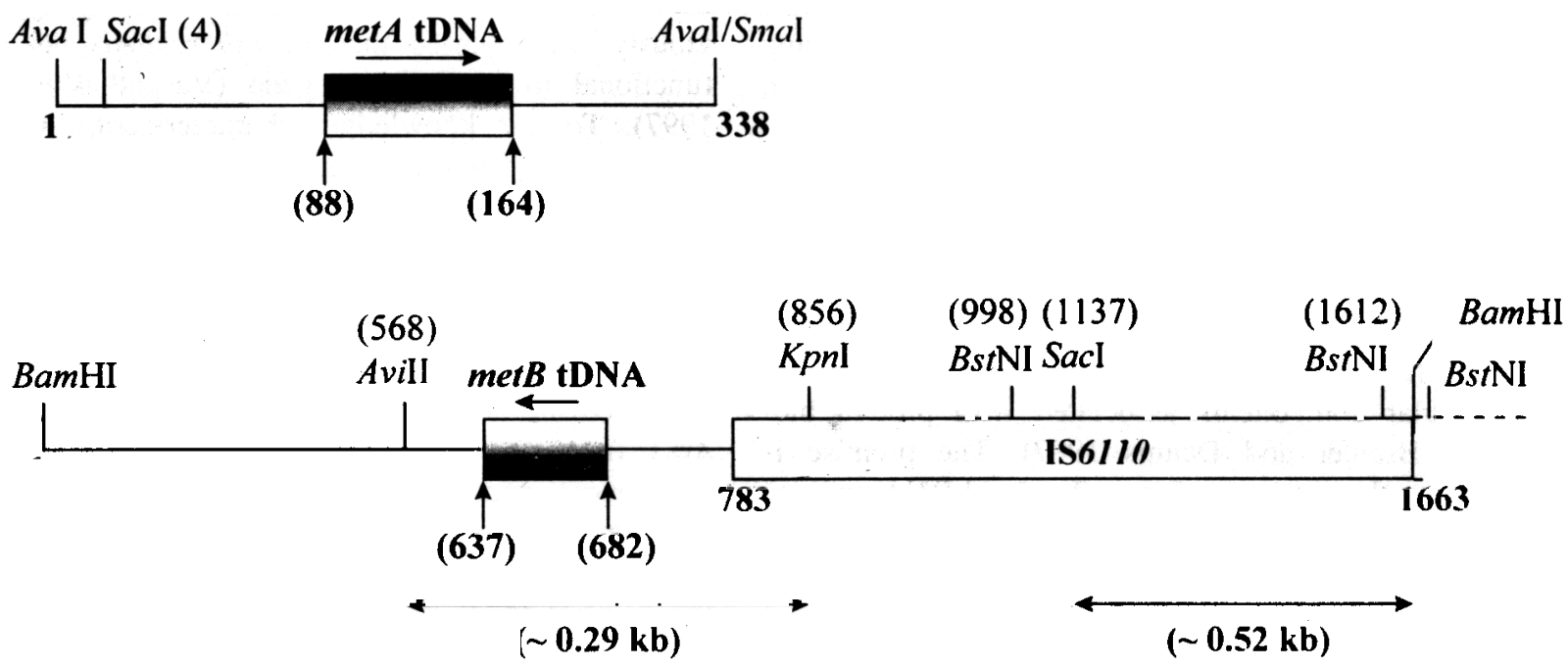

Figure 1. Restriction maps of the $0.34 \mathrm{~kb}$ Aval fragment containing metA gene (A) and, the $1.7 \mathrm{~kb}$ BamHI DNA fragment containing $m e t B$ and part of IS6110 sequence (B). The vertical arrows below the shaded boxes indicate the nucleotide positions of tDNA sequences. Horizontal arrows above the boxes indicate the orientation of metA and metB genes. Nucleotide position 783 indicates the beginning of IS6110. The 0.29 and $0.52 \mathrm{~kb}$ probes used for various Southern blot analyses are as shown. The broken lines indicate the sequence of IS6110 missing from the $1.7 \mathrm{~kb}$ clone. 


\subsection{Preparation of radiolabelled of DNA probes}

Restriction fragments were labelled by random priming (Sambrook et al 1989) in the presence of $\left[\alpha-{ }^{32} \mathrm{P}\right] \mathrm{dCTP}$ (3000 to $6000 \mathrm{Ci} \mathrm{mmol}{ }^{-1}$, Amersham) using hexanucleotide primers (New England Biolabs). The DNA
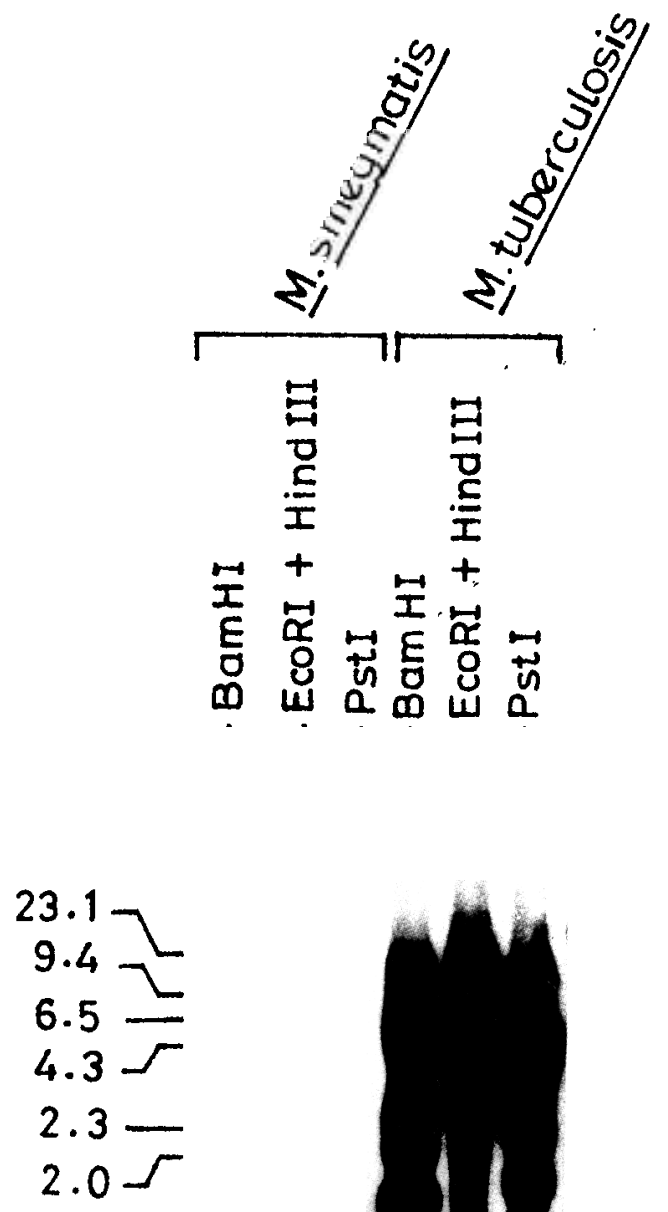

\section{6}

Figure 2. Genomic blot analysis of $M$. smegmatis SN2 (lanes 1-3) and $M$. tuberculosis H37Ra DNA (lanes 4-6) using the $0.29 \mathrm{~kb}$ Avill to KpnI fragment as probe (refer figure 1B). Restriction endonucleases used are shown on the top of the lanes. To enable detection of the initiator tRNA gene(s) in $M$. smegmatis, post hybridization washings were performed at $60^{\circ} \mathrm{C}$. Remaining conditions were as detailed in $\$ 2$. HindIII digested $\lambda$-DNA was used as marker. oligomers used as probes for Southern and colony hybridizations were $5^{\prime}$-end labelled using $\left[\gamma^{32} \mathrm{P}\right] \mathrm{ATP}(3000$ $6000 \mathrm{Ci} \mathrm{mmol}{ }^{-1}$, Amersham) and T4-polynucleotide kinase (Chaconas and van de Sande 1980).

\subsection{Hybridization and autoradiography}

Hybridization of nucleic acids fixed to the nylon membranes was performed as described (Vasanthakrishna et al 1997). Hybridizations using DNA oligomer probes were done at $40^{\circ} \mathrm{C}$ for 14 to $16 \mathrm{~h}$ and the filters were washed with SSC in the following order $-4 \times, 3 \times$, $2 \times$ for $30 \mathrm{~min}$ each; at $37^{\circ} \mathrm{C}$ in the presence of $0.1 \%$ (w/v) SDS and exposed to Konica X-ray films (Computer Graphics Ltd., India) at $-70^{\circ} \mathrm{C}$.

\subsection{Recombinant DNA techniques}

Standard techniques (Sambrook et al 1989) were followed.

\subsection{Preparation and screening of partial genomic library}

Genomic DNA $(20 \mu \mathrm{g})$ was digested with BamHI and separated on an agarose gel. DNA fragments correspond-

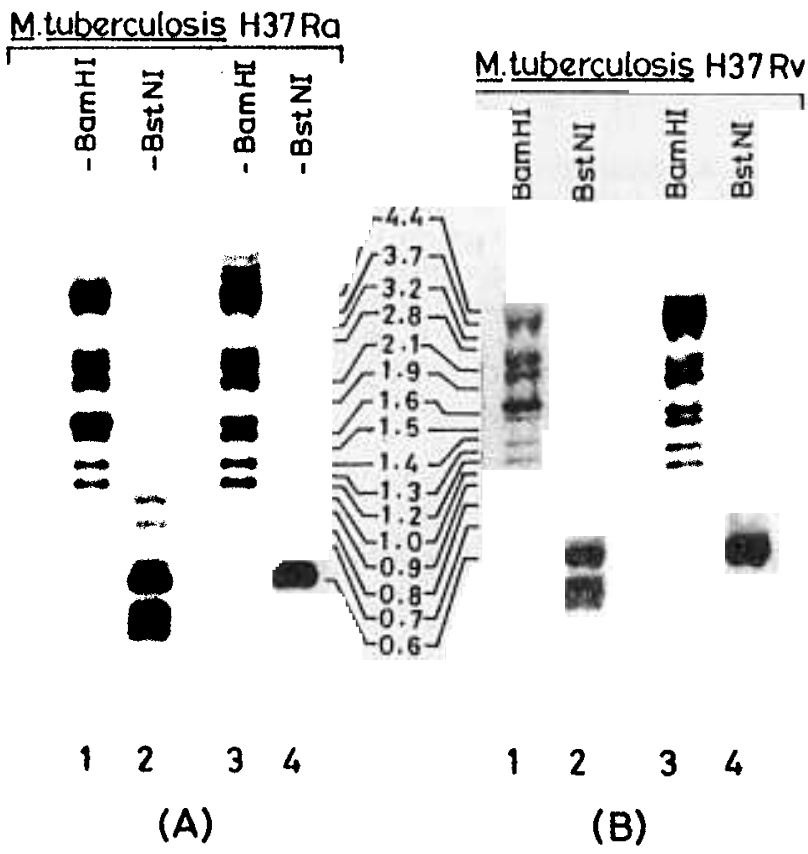

Figure 3. The presence of repeat elements in $M$. tuberculosis H37Ra and $M$. tuberculosis H37Rv: Southem blot analysis of BamHI and BstNI digested genomic DNA from $M$. tuberculosis H37Ra (A) or M. tuberculosis H37Rv (B) using the $0.29 \mathrm{~kb}$ $A$ vill to KpnI probe (lanes 1 and 2); and the $0.52 \mathrm{~kb} S a c \mathrm{I}$ to $B a m H I$ probe (lanes 3 and 4). The probes used are indicated in figure $1(\mathrm{~B})$. Hind II and HindIII digested $\lambda$-DNA was used as marker. 
ing to 5.5 to $7.0 \mathrm{~kb}$ were spin eluted $(5000 \mathrm{~g}$ for $10 \mathrm{~min}$ in a microfuge) by placing the corresponding gel piece over polyester wool in a $0.5 \mathrm{ml}$ Eppendorf tube with a punctured bottom, fitted into $1.5 \mathrm{ml}$ Eppendorf tube. DNA was extracted with phenol/chloroform $(1: 1 \mathrm{v} / \mathrm{v})$, precipitated with ethanol and cloned into BamHI site of pTZ18R. Recombinants were screened by colony hybridization using $\left.{ }^{32} \mathrm{P}\right]$-labelled 'anticodon oligo'.

\subsection{DNA sequence analysis}

DNA sequencing was performed by dideoxy chain termi

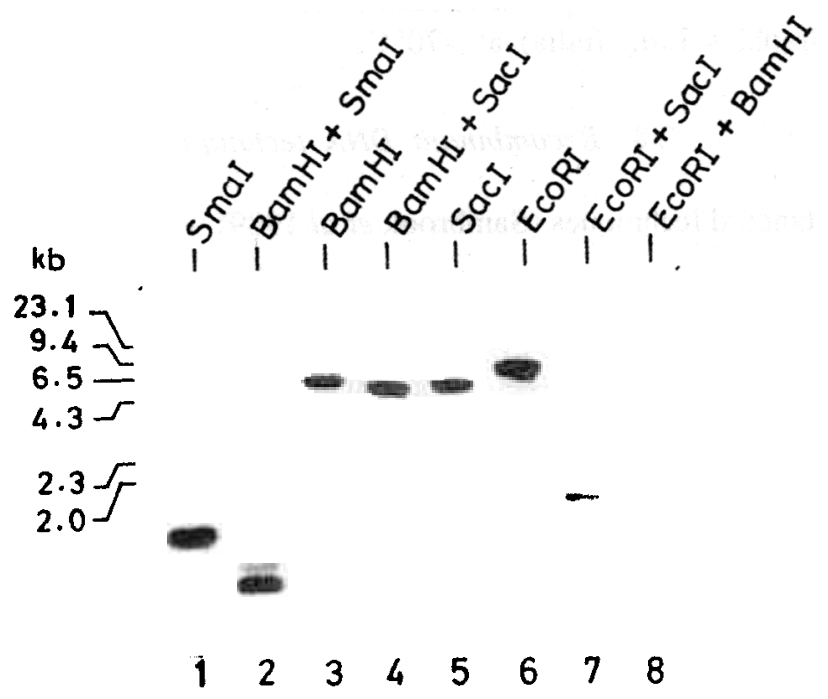

Figure 4. Southem blot of $M$. tuberculosis H37Ra genomic DNA digested with various restriction endonucleases and probed with the $0.34 \mathrm{~kb} \mathrm{Aval}$ fragment (harbouring metA, figure $1 \mathrm{~A}$ ). Approximate sizes of the various fragments $(\mathrm{kb})$ are as follows. Lane 1, 3.2 and 1.4; lane 2, 1.0 and 0.8 ; lane 3,6 and 1.7; lane $4,5.5$ and 1.1 ; lane 5,6 and 1.8 ; lane $6,8.5$; lane 7,6 and 1.8 ; and lane 8,6 and 17.7 . (The sizes of the metA containing fragments are indicated in bold). nation method (Sanger et al 1977) using either Sequenase version 2.0 (US Biochemicals) or the DNA Cycle Sequencing System (Gibco BRL).

\section{Results and discussion}

\section{3 metA and metB loci}

Southern blot analysis of BamHI digested genomic DNA of $M$. tuberculosis H37Ra using the 'anticodon oligo' showed two hybridizing bands of approximately $6.0 \mathrm{~kb}$ and $1.7 \mathrm{~kb}$ harbouring $m e t A$ and $m e t B$, respectively (Vasanthakrishna et al 1997). Further analyses showed that the $0.34 \mathrm{~kb} A v a I$ fragment represented the same initiator tRNA gene (metA) as the one present in the $6.0 \mathrm{~kb} \mathrm{BamHI}$ fragment. Isolation and sequencing of the $0.34 \mathrm{~kb} \mathrm{Aval}$ (exact size, $0.338 \mathrm{~kb}$ ) and the $1.7 \mathrm{~kb} \mathrm{BamHI}$ (exact size, $1.663 \mathrm{~kb}$ ) genomic fragments harbouring metA and metB respectively has been described (EMBL accession numbers Y08623 and Y08970; Vasanthakrishna et al 1997). Figure 1 shows the restriction maps of the two clones. The sequence of metA revealed a region of 77 nucleotides (tDNA) from position 88 to 164 which is identical with that of $M$. smegmatis initiator tRNA sequence determined by RNA finger printing (Vani $e t$ al 1984). Surprisingly, the $1.7 \mathrm{~kb}$ BamHI fragment showed only a short region of sequence complementary to positions 31-75 of the initiator tRNA (standard tRNA numbering, Rich and RajBhandary 1975; Sprinzl et al 1989). Sequence homology search of the metB locus in the EMBL nucleotide data bank showed absolute identity $(>99.6 \%)$ in the sequence downstream of position 782 in the metB clone to an insertion element, IS 6110 or IS987. The IS6110 is a repeat element of $1361 \mathrm{bp}$ with a copy number of up to 20 in the $M$. tuberculosis complex (Poulet and Cole 1995 and references cited therein; Thierry et al 1990). The BamHI site at the end

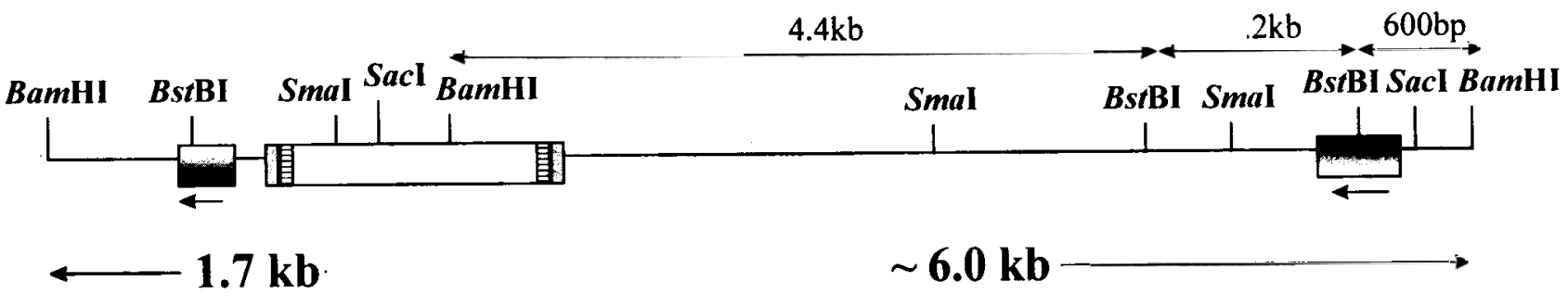

IS6110

Figure 5. Linkage map of $6.0 \mathrm{~kb}$ and $1.7 \mathrm{~kb}$ BamHI fragments. Relevant restriction sites are as indicated. The shaded boxes refer to the tDNA sequences of metA and metB. IS6110 is represented by an open box flanked by the inverted (IR) and direct (DR) repeats. Sizes of the fragments released by BstBI and BamHI digestion of the 6.0 kb fragment (figure 6C) are as shown. 
of the cloned $1.7 \mathrm{~kb}$ fragment (position 1663) corresponds to the $B a m \mathrm{HI}$ site of the IS element at position 881 (IS6110 numbering), hence the metB clone lacks the IS6110 sequence downstream of the BamHI site.

\subsection{Organization of IS6110, metA and metB}

Southern blot analysis of the genomic DNA from $M$. smegmatis SN2 and $M$. tuberculosis H37Ra (figure 2) using a $0.29 \mathrm{~kb}$ AvilI to KpnI fragment from the $1.7 \mathrm{~kb}$ clone (figure 1B) showed several strong bands in $M$. tuberculosis (figure 2, lanes 4-6), suggesting multiple copies of IS6 110 in the genome. Since $M$. smegmatis does not harbour IS6110 (Poulet and Cole 1995) the distinct bands in lanes 1-3 most likely correspond to the initiator tRNA gene(s).

To further investigate the copy number of the IS element, we used a second probe $(0.52 \mathrm{~kb})$ from a region internal to IS6110 (SacI-BamHI fragment, see figure 1B). Southern blot analyses of BamHI and Bst $\mathrm{NI}$ digested genomic DNA from $M$. tuberculosis H37Ra and H37Rv using the $0.29 \mathrm{~kb}$ probe are shown in lanes 1 and 2 (figure $3 \mathrm{~A}, \mathrm{~B}$ ) and those to $0.52 \mathrm{~kb}$ probe in lanes 3 and

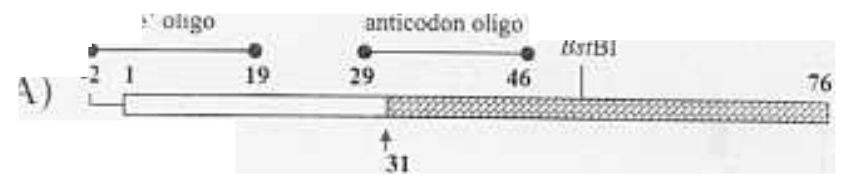

123

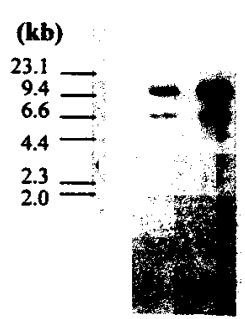

(B)
12

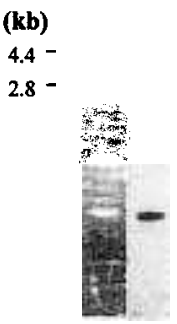

(C)
Figure 6. Southern blot analyses. (A) The box (1-76) indicates the metA tRNA while the cross-hatched region $(31-76)$ shows the overlap with metB tRNA. The positions of the 5' end DNA oligomer (positions -2 to 19) and the anticodon oligo (positions 29-46) used as probes for Southern analysis are indicated on the top. (B) Southern blot of the genomic DNA from $M$. smegmatis (lane 1) $M$. tuberculosis H37Ra (lane 2) and H37Rv (lane 3 ), digested with the BstBI and probed with $\left[{ }^{32} \mathrm{P}\right] 5^{\prime}$-end labelled anticodon oligonucleotide. Hind $I I I$ digested $\lambda$-DNA was used as marker. (C) BstBI and BamHI digestion of $6.0 \mathrm{~kb}$ BamHI clone. Photograph of ethidium bromide stained agarose gel and the corresponding Southern blot probed with $\left[{ }^{32} \mathrm{P}\right]$ end labelled $5^{\prime}$ DNA oligomer are shown in lanes 1 and 2 , respectively. The sizes of the various fragments are as indicated (also refer to figure 5 ). The $2.8 \mathrm{~kb}$ band corresponds to $\mathrm{pTZ18R}$ vector.
4 (figure $3 A, B$ ). Comparison of lanes $1-3$ in figure $3(A)$ with the corresponding lanes in figure $3(\mathrm{~B})$ indicates a similar pattern of hybridization in the BamHI and BstNI genomic digests of $M$. tuberculosis H37Ra and H37Rv. Since these sites are also present within IS6110 (figure $1 B)$, the results suggest identical organization of the repeat element in the two strains. Further, as IS6110 contains three internal BstNI sites, digestion of the genomic DNA with $B s t$ NI is expected to release internal fragments of approximately $0.61 \mathrm{~kb}$ and $0.05 \mathrm{~kb}$ from all copies of IS6110. As expected, only the $0.61 \mathrm{~kb}$ fragment was detected by hybridization to $0.52 \mathrm{~kb}$ probe (lane 4 , figure 3A,B) which further establishes that all the bands in the BamHI digests (lanes 1 and 3) belong to IS6110. Also, strong hybridization of $0.29 \mathrm{~kb}$ probe (which contains $m e t B$ ) to the $1.7 \mathrm{~kb}$ band in the $B$ am HI digests [compare figure $3(\mathrm{~A})$ (lane 1) to figure 3(B) (lane 1)] suggests identical organization of $m e t B$ in both the strains of $M$. tuberculosis.

Southern blot of $M$. tuberculosis H37Ra DNA probed with the $0.34 \mathrm{~kb} \mathrm{AvaI}$ fragment (figure 1A) to distinguish $m e t A$ (strong signal) from metB (weak signal) has allowed further analysis of the linkage of metA and metB (figure 4). A single band of $\sim 8.5 \mathrm{~kb}$ in the EcoRI digest (lane 6) shows that $m e t A$ and $m e t B$ loci are linked over a distance of $8.5 \mathrm{~kb}$. The sizes of the two bands of 1.7 and $6.0 \mathrm{~kb}$ in the BamHI digest (lane 3) remain unaltered upon further digestion with EcoRI (lane 8). This observation together. with the combined size of these fragments $(7.7 \mathrm{~kb})$ suggests that they are located within the $8.5 \mathrm{~kb}$ EcoRI fragment. To a first approximation, the $1.7 \mathrm{~kb}$ and the $6.0 \mathrm{~kb} \mathrm{BamHI}$ DNA fragments should be adjacent to each other. Digestion with $S m a I$ released metA in an $\sim 1.4 \mathrm{~kb}$ fragment (lane 1), which upon further digestion with BamHI generated a band of $\sim 0.8 \mathrm{~kb}$ (lane 2). As a SmaI site is found immediately downstream of metA (figure 1A), these results suggest that metA is located within $0.8 \mathrm{~kb}$ from one end of the $6.0 \mathrm{~kb} \mathrm{BamHI}$ fragment. Sizes of the various fragments harbouring met $B$ wherever deducible are as expected (lanes 2, 3, 4 and 8). Fragments of $\sim 1.8 \mathrm{~kb}$ encompassing $\mathrm{met} B$ (lanes 5 and 7 ) are most likely due to the presence of a $S a c I$ site $\sim 0.7 \mathrm{~kb}$ upstream of position 1 of the $1.7 \mathrm{~kb}$ BamHI fragment.

\subsection{Isolation and partial sequencing of the $6.0 \mathrm{~kb}$ BamHI fragment; and linkage of metA and metB loci}

From the above data it was not possible to deduce the linkage of the two met gene loci. Moreover, the results did not clarify whether or not there is a complete copy of IS6110 at the initiator tRNA locus. To address these questions we screened a partial genomic library of BamHI digested $M$. tuberculosis H37Ra DNA $(5.5$ to $7.0 \mathrm{~kb}$ fragments). Two clones having a $6.0 \mathrm{~kb} B a m \mathrm{HI}$ insert (as indicated in figure 5) in opposite orientations were used for further characterization. Sequence analysis 
Table 1. Examples of integrative elements carrying $3^{\prime}$ half of tRNA gene in the attachment site (attP).

\begin{tabular}{|c|c|c|c|}
\hline $\begin{array}{l}\text { Integrative } \\
\text { elements }\end{array}$ & Host range & $\begin{array}{l}3^{\prime} \text { half of tRNA } \\
\text { genes associated } \\
\text { with the attP site }\end{array}$ & Remarks \\
\hline SLP & Streptomyces species & $\mathrm{tRNA}^{\mathrm{tyr}}$ & $\begin{array}{l}17 \mathrm{~kb} \text { conjugative plasmid } \\
\text { (Reiter et al. 1989) }\end{array}$ \\
\hline pMEA 100 & Nocardia mediterranei & tRNA $^{\text {phe }}$ & $\begin{array}{l}\text { Transmissible plasmid (Reiter } \\
\text { et al 1989) }\end{array}$ \\
\hline pSAM 2 & Streptomyces species & tRNA ${ }^{\text {pro }}$ & $\begin{array}{l}11 \mathrm{~kb} \text { conjugative plasmid } \\
\text { (Mazodier et al 1990) }\end{array}$ \\
\hline HPlcl & Haemophilus influenze & tRNA $^{\text {leu }}$ & $\begin{array}{l}\text { Bacteriophage (Hauser et al } \\
\text { 1992) }\end{array}$ \\
\hline P4 & E. coli & $\operatorname{tRNA}^{\text {leu }}$ & $\begin{array}{l}\text { Bacteriophage (Pierson et al } \\
\text { 1987) }\end{array}$ \\
\hline Bacteriophage 16-3 & Rhizobium meliloti & tRNA $^{\text {pro }}$ & $\begin{array}{l}\text { Bacteriophage (Papp et al } \\
\text { 1993) }\end{array}$ \\
\hline NBU1 & $\begin{array}{l}\text { Bacteroides species, } \\
\text { E. coli }\end{array}$ & $\operatorname{tRNA}^{\text {leu }}$ & $\begin{array}{l}\text { Nonreplicative, mobilized in } \\
\text { trans by Tns (Shoemaker et } \\
\text { al 1996) }\end{array}$ \\
\hline SSV1 & Sulfolobus strain B12 & $\mathrm{tRNA}^{\mathrm{arg}}$ & $\begin{array}{l}15.5 \mathrm{~kb} \text { plasmid (Reiter et al } \\
1989 \text { ) }\end{array}$ \\
\hline
\end{tabular}
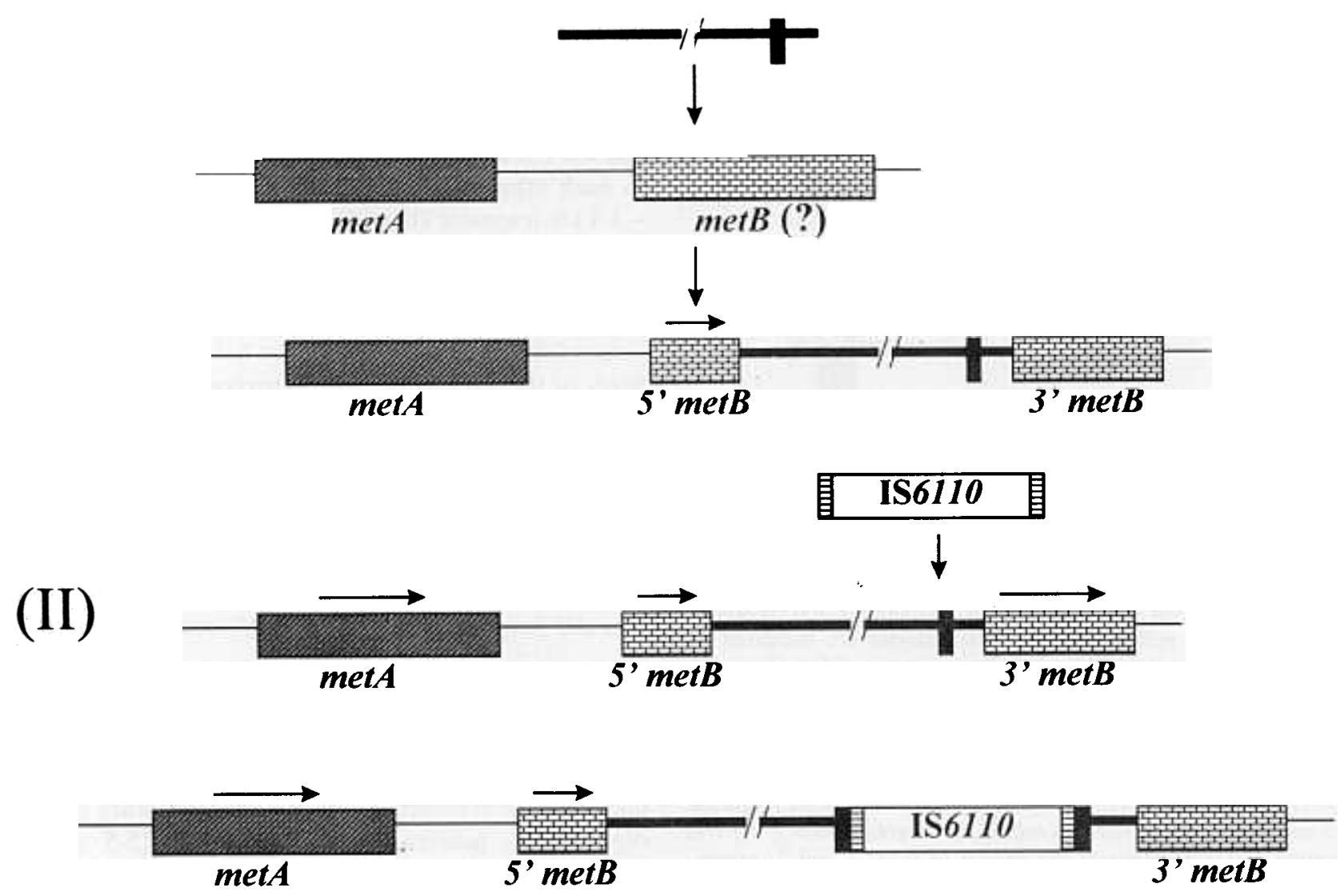

Figure 7A. For caption, see page No. 108. 
revealed the presence of IS6110, corresponding to the sequence downstream of the BamHI site (position 881 , IS6110 numbering) on one end, and metA sequence on the other. The identity of the upstream (5'-TGAACCGCCCCGGCATGTCCGGAGACTC-3') and downstream (5'-GAGTCTCCGGACTCACCGGGGCGGTTCA-3') inverted repeats of IS6110 flanked by direct repeats (ATT) was also confirmed (figure 5). These results are in agreement with the predictions from the data shown in figure 4 and unambiguously establish that the $1.7 \mathrm{~kb}$ and $6.0 \mathrm{~kb}$ BamHI fragments are contiguous and, metA and metB are separated by IS6110.

\section{4 tRNA gene copy numbers in slow- and fast-growing mycobacteria}

The slow growing mycobacteria possess one operon for ribosomal RNA genes ( $r r n)$ as opposed to two in the fast growing mycobacteria (Clark-Curtis 1990; Ji et al 1994a,b). Our studies show that while $M$. tuberculosis $\mathrm{H} 37 \mathrm{Ra}$ and H37Rv contain two initiator tRNA loci; only one of them, metA, represents an intact copy of the transcriptionally active gene. Contrary to the presence of two copies of ribosomal RNA genes, our results (figure 2) suggested a single copy of the initiator tRNA gene in $M$. smegmatis SN2. To establish the copy number in this fast growing mycobacteria, we performed a Southern blot analysis of BstBI digested genomic DNA using the anticodon oligo as probe. The BstBI site corresponds to $\mathrm{T} \psi \mathrm{C}$ loop sequence region and is present in all the initiator tRNA genes. Southern blot analysis using anticodon oligo as probe ensures that the number of hybridizing bands in the BstBI digested genomic blots exactly corresponds to the number of initiator tRNA genes in the genome. Consistent with our earlier obser-

(B)

(I)
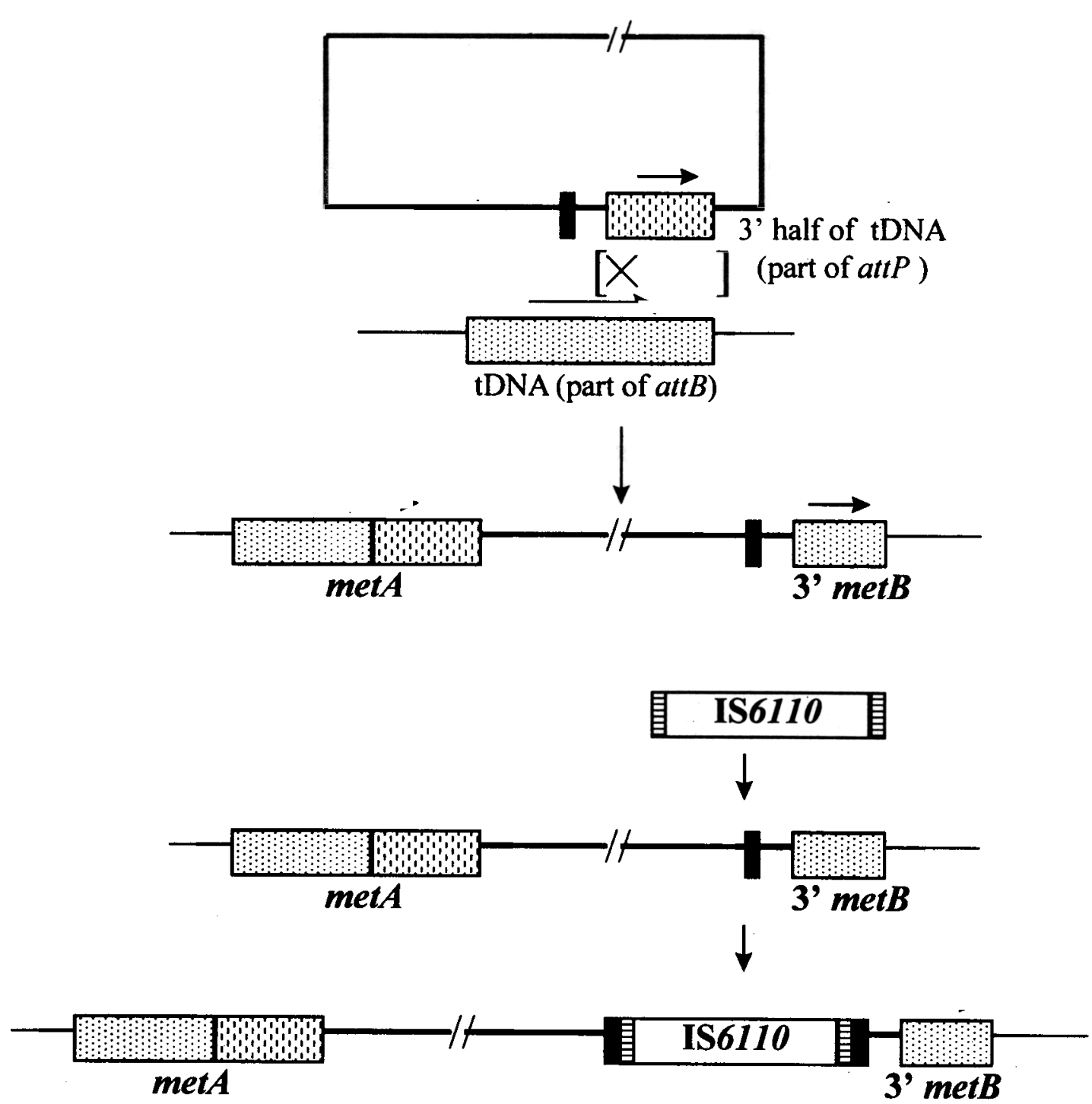

Figure 7B. For caption, see page No. 108. 


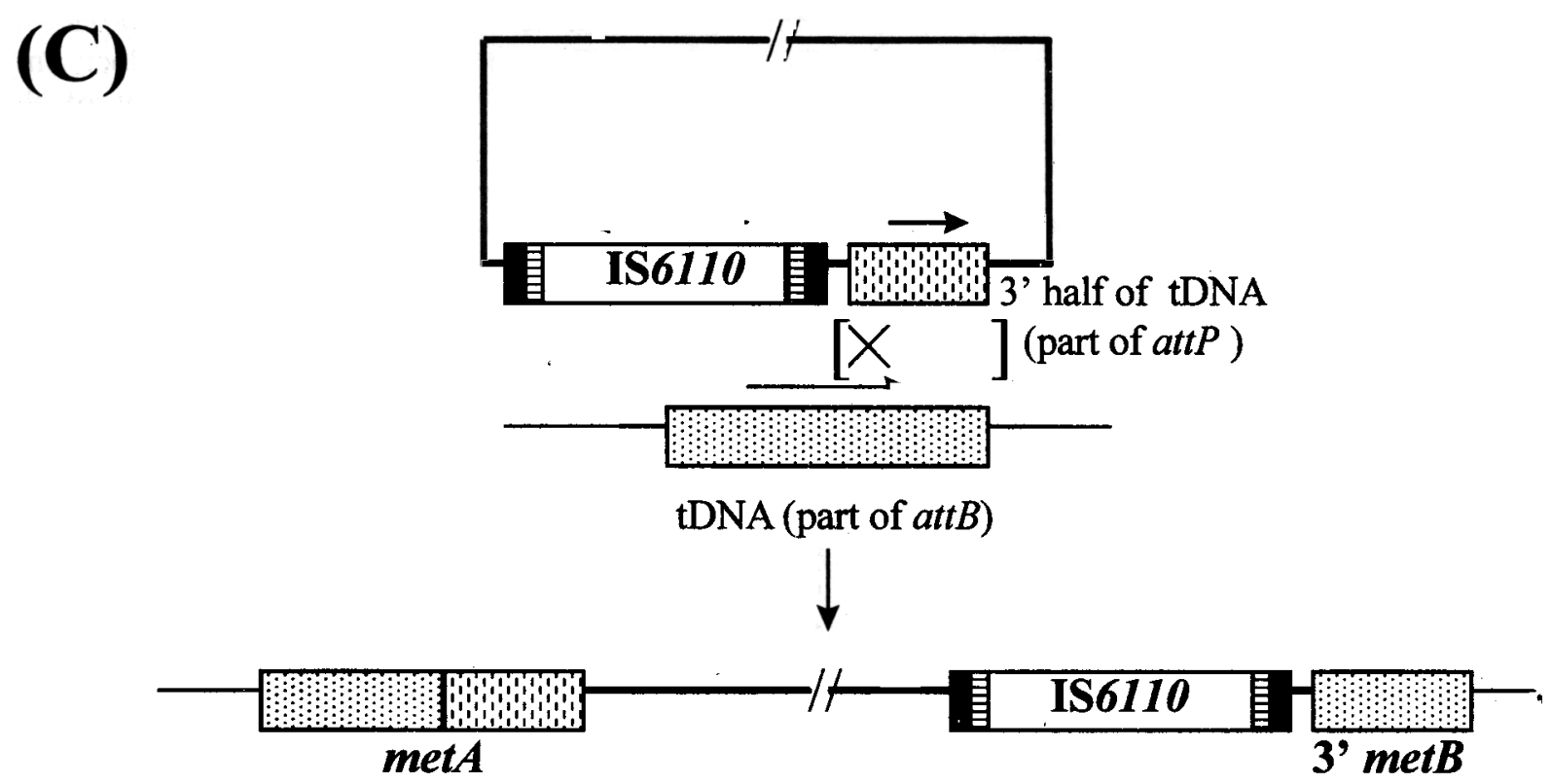

Figure 7. A schematic of the various models proposed to explain the origin of the initiator tRNA gene locus. (A) The shaded boxes show two copies of tRNA genes (metA and metB). Step I: disruption of metB by an insertion element (dark line with a break). Step II: Integration of IS6110 into the first insertion sequence. (B) Site specific recombination between the integrative plasmid carrying the $3^{\prime}$ half of the initiator gene (as part of attP) and the initiator tRNA gene of the host (part of attB). The second event of insertion can then lead to integration of IS6110. (C) A variation of the model in (B). The integrative plasmid also carries the IS6110 and hence a single recombination event results in the integration of $3^{\prime}$ half of metB and IS6110. For the sake of simplicity, the sites of recombination in (B) (step I) and (C) have been shown towards the left terminus of the $3^{\prime}$ half of the tDNA sequence of attP. However, recombination could occur anywhere within the tDNA sequence, as indicated by square brackets.

vation (figure 2), M. smegmatis showed a single band (lane 1, figure 6B) confirming the presence of a single initiator tRNA gene in this fast growing species. As expected, $M$. tuberculosis $\mathrm{H} 37 \mathrm{Ra}$ and H37Rv show two identical size bands corresponding to $m e t A$ and $m e t B$ (lanes 2 and 3, figure 6B). Further, Southern blot analysis of BamHI digested DNA using metA as probe detected two bands of $6.0 \mathrm{~kb}$ (harbouring $m \dot{e} t A$ ) and $1.7 \mathrm{~kb}$ (harbouring metB) in both the strains (data not shown). Taken together, these results suggest an identical organization of metA and metB in $M$. tuberculosis H37Ra and H37Rv.

\subsection{Insertion sequences and the origin of metB}

Southern blots of BamHI and BstNI digested genomic DNA (figure 3) showed 9 to 12 clearly resolved bands. However, the contig map of $M$. tuberculosis $\mathrm{H} 37 \mathrm{Rv}$ (Philipp et al 1996) revealed 16 copies of the IS6110 in the genome thus suggesting that some of the bands in figure 3 may contain more than one copy of the IS6110. In any case, the metB locus represents the first example in mycobacteria where a mobile genetic element is seen to flank a tRNA-like sequence. There are a large number of reports where a tRNA loci in other eubacteria and archaebacteria have been shown to be the targets for site specific integration of various genetic elements (Inokuchi and Yamao 1995; Mazodier et al 1990; Papp et al 1993; Reiter et al 1989; Shoemaker et al 1996; Vogtli and Cohen 1992). However, as suggested by the presence of a $100 \mathrm{bp}$ intervening stretch between the truncated tRNA-like sequence and IS 6110 beginning at position 783 (see figures 1B and 5), integration of IS6110 at the metB locus is unlikely to be the primary event in the origin of the truncated tRNA-like sequence in $M$. tuberculosis.

A schematic diagram of the possible events which could have led to the present status of the initiator tRNA gene locus are shown in figure $7(\mathrm{~A}-\mathrm{C})$. met $B$ could be a remnant of a previously active second copy of the initiator tRNA gene and evolved as a result of two insertion events. The first event disrupted the tRNA gene, and the second event led to the integration of IS6110 into the first insertion sequence (figure 7A). This not only explains the presence of $100 \mathrm{bp}$ sequence between $m e t B$ and IS6110, but also predicts the presence of $5^{\prime}$ half of metB somewhere downstream of the insertion sequence(s). To test this model, we performed a Southern blot analysis on the Bst $\mathrm{BI}$ digest of the $6.0 \mathrm{~kb} \mathrm{BamHI}$ fragment, using an oligomeric probe corresponding to 
the $5^{\prime}$-part of the initiator tRNA (figure 6A,C). In this experiment, we failed to detect a hybridizing signal which could correspond to the $5^{\prime}$ half of the met $B$ tRNA. However, as expected, the $600 \mathrm{bp}$ fragment harbouring the $5^{\prime}$ half of the metA gene was detected. While our failure to detect the $5^{\prime}$ half of the met $B$ does not support this model, the interpretation is subject to the assumption that the $5^{\prime}$ half of metB did not diverge as a result of accumulation of mutations. Alternatively, it is likely that metB was introduced into the $M$. tuberculosis genome by an integrative plasmid. Many such plasmids carry the 3' half of the tRNA gene as a part of the attachment site (attP). Although their integration into the genome displaces the $3^{\prime}$ half of the host tRNA gene (part of $a t t B)$, they reconstitute a complete copy of the tRNA gene with the $3^{\prime}$ part coming from attP (table 1 and the references cited therein). As shown in figure 7(B), a second event of insertion of IS6110 into the region next to the met $B$ sequence could explain the origin of $m e t B$ locus. Another likely possibility is that the integrative plasmid carried both the metB and IS6110 element, and a single insertion event could have resulted in the present day initiator tRNA locus (figure 7C).

Further, many bacteriophages are also known to carry $3^{\prime}$ half of a tRNA gene as a part of attP. Thus a variation of the models shown in figure $7(B, C)$ could be that metB came as part of a temperate phage (Reiter et $a l 1989$ and the references cited therein; Papp et al 1993). Since, the distance between metA and $m e t B$ is only $\sim 6.0 \mathrm{~kb}$, we consider the insertion of a temperate phage (average size $\sim 40-50 \mathrm{~kb}$ ) an unlikely possibility. To gain further insight into the mechanism of origin of $m e t B$, we performed homology search of sequences neighboring $m e t B$. However, the sequence revealed no homology to any known insertion elements, integrative plasmids or bacteriophages. Nevertheless, the question remains, 'Is $m e t A$ the original initiator tRNA gene?'

\section{Acknowledgements}

We thank Ms L Ramakrishna and Ms S Thanedar for their contributions in the preliminary characterization of the $6.0 \mathrm{~kb}$ BamHI fragment, and $\mathrm{Dr} \mathrm{K}$ Muniyappa for critical reading of this manuscript. This work was supported by research grants from the Council of Scientific and Industrial Research, and the Department of Biotechnology, New Delhi.

\section{References}

Bercovier H, Kafri O and Sela S 1986 Mycobacteria possess a surprisingly small number of ribosomal RNA genes in relation to the size of their genome; Biochem. Biophys. Res. Commun. 136 1136-1141

Bhargava S, Tyagi A K and Tyagi J S 1990 tRNA genes in mycobacteria: organization and molecular cloning; J. Bacteriol. 172 2930-2934

Bremer H and Dennis P P 1987 Modulation of chemical composition and other parameters of the cell growth rate; in Escherichia coli and Salmonella typhimurium: Cellular and molecular biology (eds) F C Neiddhardt, J L Ingraham, K B Low, B Magasanik, M Schaechter and H E Umbarger (Washington DC: American Society for Microbiology) pp 1527-1542

Chaconas G and van de Sande J H 1980 5'-32P labeling of RNA and DNA restriction fragments; Methods Enzymol. 65 $75-85$

Clark-Curtis J E 1990 Genome structure of mycobacteria; in Molecular biology of the mycobacteria (ed.) J McFadden (London: Academic Press) pp 77-95

Hauser M A and Scocca J J 1992 Site specific integration of the Haemophilus influenzae bacteriophage HP1; J. Biol. Chem. 267 6859-6864

Inokuchi $\mathrm{H}$ and Yamao $F 1995$ Structure and expression of prokaryotic tRNA genes; in tRNA structure biogenesis and function (eds) D Soll and U L RajBhandary (Washington DC: ASM Press) pp 17-30

Ishii S, Kuroki K and Imamoto F 1984 tRNA $^{\text {f2met }}$ gene in the leader region of the nusA operon in Escherichia coli; Proc. Natl. Acad. Sci. USA $81409-413$

Ji Y E, Colston M J and Cox R A 1994a Nucleotide sequence and secondary structures of precursor 16S rRNA of slowgrowing mycobacteria; Microbiology 140 123-132

Ji Y E, Colston M J and Cox R A 1994b The ribosomal RNA rrn operons of fast growing mycobacteria: primary and secondary structures and their relation to $r r n$ operons of pathogenic slow growers; Microbiology 140 2829-2840

Kenri T, Imamoto F and Kano Y 1994 Three tandemly repeated structural genes encoding tRNA ( $f 1 \mathrm{Met}$ ) in the metZ operon of Escherichia coli K-12; Gene 138 261-262

Maxam A M and Gilbert W A 1980 Sequencing end-labeled DNA with base-specific chemical cleavage; Methods Enzymol. 65 499-560

Mazodier P, Thomson C and Boccard F 1990 The chromosomal integration site of the Streptomyces element pSAM2 overlaps a putative tRNA gene conserved among actinomycetes; $\mathrm{Mol}$. Gen. Genet. 222 431-434

Musser J M 1995 Antimicrobial agent resistance in mycobacteria: molecular genetics insights; Clin. Microbiol. Rev. 8 496-594

Nagaraja V and Gopinathan K P 1980 Requirement of calcium ions in Mycobacteriophage 13 DNA infection and propagation; Arch. Microbiol. 124 249-254

Papp I, Dorgai L, Papp P, Jonas E, Olasz F and Orosz L 1993 The bacterial attachment site of the temperate Rhizobium phage 16-3 overlaps the $3^{\prime}$ end of a putative proline tRNA gene; Mol. Gen. Genet. 240 258-264

Pelicic V, Jackson M, Reyrat J M, Jacobs W R Jr, Gicquel B and Guilhot C 1997 Efficient allelic exchange and transposon mutagenesis in Mycobacterium tuberculosis; Proc. Natl. Acad. Sci. USA 94 10955-10960

Philip W J, Poulet S, Eiglmeir K, Pascopella L, Balasubramanian B H, Bergh S, Bloom B R, Jacobs W R Jr and Cole S T 1996 An integrated map of the genome of the tubercle bacillus Mycobacterium tuberculosis $\mathrm{H} 37 \mathrm{Rv}$ and comparision with $M y$ cobacterium leprae; Proc. Natl. Acad. Sci. USA 93 3132-3137

Pierson III L S and Kahn M L 1987 Integration of satellite bacteriophage P4 in Escherichia coli DNA sequences of the phage and host regions involved in site-specific recombination; J. Mol. Biol. 196 487-496

Poulet S and Cole S T 1995 Repeated DNA sequences in mycobacteria; Arch. Microbiol. 163 79-86

Reed K C and Mann D A 1985 Rapid transfer of DNA from 
agarose gels to nylon membranes; Nucleic Acids Res. 13 7207-7221

Reiter W-D, Palm P and Yeats S 1989 Transfer RNA genes frequently serve as integration sites for procaryotic genetic elements; Nucleic Acids Res. 17 1907-1914

Rich A and RajBhandary U L 1975 Transfer RNA: Molecular structure sequence and properties; Annu. Rev. Biochem. 45 805-860

Sambrook J, Fritsch E F and Maniatis T 1989 Molecular cloning: A laboratory mannual 2nd edition (New York: Cold Spring Harbor Laboratory)

Sanger F, Nicklen S and Coulson A R 1977 DNA sequencing with chain-terminating inhibitors; Proc. Natl. Acad. Sci. USA 74 5463-5467

Shoemaker N B, Wang G R and Salyers A A 1996 The Bacteroides mobilizable element NBU1 integrates into the $3^{\prime}$ end of a Leu-tRNA gene and has an integrase that is a member of the Lambda integrase family; J. Bacteriol. $1783594-3600$
Sprinzl M, Hartman T, Weber J, Blank J and Zeidler R 1989 Compilation of tRNA sequences and sequences of tRNA genes; Nucleic Acids Res. 17 rl-r172

Thierry D, Cave M D, Eisenach K D, Crawford J T, Bates J H, Gicquel B and Guelsdon J L 1990 IS6110 an IS-like element of Mycobacterium tuberculosis complex; Nucleic Acids Res. 18188

Vani B R, Ramakrishnan T, Kuchino Y and Nishimura S 1984 Nucleotide sequence of initiator tRNA from Mycobacterium smegmatis; Nucleic Acids Res. 12 3933-3936

Vasanthakrishna M, Kumar N V and Varshney U 1997 Characterization of the initiator tRNA gene locus and identification of a strong promoter from Mycobacterium tuberculosis; Microbiology 143 3591-3598

Vogtli M and Cohen S N 1992 The chromosomal integration site for the Streptomyces plasmid SLP1 is a functional tRNA Tyr gene essential for cell viability; Mol. Microbiol. 6 30413050

MS received 10 March 1998; accepted 15 May 1998

Corresponding editor: K MUNIYAPPA 